\title{
"Terrorism and Homeland Security: Perspectives, Thoughts, and Opinions," Edited by Dale L. June (Boca Raton, FL: CRC Press, 2011)
}

Mark J. Roberts

Follow this and additional works at: https://digitalcommons.usf.edu/jss

Part of the Defense and Security Studies Commons, National Security Law Commons, and the Portfolio and Security Analysis Commons

pp. 69-72

\section{Recommended Citation}

Roberts, Mark J.. "'Terrorism and Homeland Security: Perspectives, Thoughts, and Opinions," Edited by Dale L. June (Boca Raton, FL: CRC Press, 2011)." Journal of Strategic Security 4, no. 3 (2011) : 69-72.

DOI:

http://dx.doi.org/10.5038/1944-0472.4.3.6

Available at: https://digitalcommons.usf.edu/jss/vol4/iss3/7

This Book Review is brought to you for free and open access by the Open Access Journals at Digital Commons @ University of South Florida. It has been accepted for inclusion in Journal of Strategic Security by an authorized editor of Digital Commons @ University of South Florida. For more information, please contact digitalcommons@usf.edu. 
"Terrorism and Homeland Security: Perspectives, Thoughts, and Opinions," Edited by Dale L. June (Boca Raton, FL: CRC Press, 2011) 


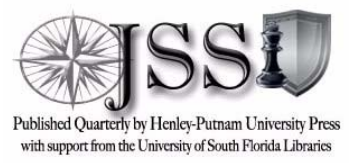

Terrorism and Homeland Security: Perspectives, Thoughts, and Opinions. Edited by Dale L. June. Boca Raton, FL: CRC Press, 2011. ISBN: 978-1-4200-9306-3. Photographs. Index. Notes. Sources Cited. Pp. xxxviii, 355. \$79.95.

Terrorism and Homeland Security is an eclectic anthology of twenty-two essays written by a diverse mix of personalities, each with a different perspective on a vast topic with myriad facets. Editor Dale L. June has an extensive national security background that encompasses duty with the U.S. Secret Service, the U.S. Army, a couple of California police departments, various martial arts associations, and also various universities. His approach in putting the book together is to mix both practical and academic points of view, thereby attempting to meld many disparate ideas into a multi-faceted, woven tapestry. In terms of its relative value to the field of Homeland Security studies, it is above average, but is neither outstanding nor substandard. The book's diversity serves simultaneously as its strength and weakness. It is truly a mix of perspectives, thoughts, and opinions. Although uneven in its quality, there is in truth something for everyone. However, some of the essays are more existentially ivory-towered than useful in a field already crowded with tomes competing for your textbook dollar. In a bottom-line society, the more whimsical essays degrade the overall value of the book, as they offer little to no value to the better outlining of challenges of the homeland security vocation. Factual errors also detract from the book's credibility.

The Foreword, written by a university student, is long on idealism and short on practicality. The informality, presumptuousness, and naiveté make it more appropriate for the editorial page of a newspaper or magazine, not a book seeking to be considered a serious tome on the topic.

Dale L. June's opening essay provides a look at terrorism past and present, outlining how outsourcing, globalization, McDonaldization, and Disneyization have become part of the national security landscape. June is an erudite intellectual who sprinkles quotes from a wide array of historical personalities to emphasize his point. There are some spelling errors and a glaring factual error: al-Qaida did not conduct the suicide attack on the Marine barracks in Beirut (18); it was Hizbollah, sponsored by Iran. The essay proceeds to channel surf from terrorism to emergency 
response to the long-neglected discipline of U.S. civics. This has the effect of trying to cram too many perspectives into a very small space. The writing tells me more about the author's biases than the topic itself, and the stream-of-consciousness approach is an inch deep and a mile wide.

The second essay by Michael Savasta gives a tight, concise view of modern terrorism and would have been better served in the lineup as the first essay. Savasta discusses counterterror (CT) operations, partnering with international entities, and the impact of mass media. His erroneous statement that the Department of Transportation is responsible for security at airports (43) is the weak point in the essay (it is the Department of Homeland Security).

Dale L. June's discussion of an al-Qaida manual provides a useful overview of the group's evolution. The most relevant part of the essay explores the question of why they hate us and is one of the book's highlights.

Dr. A. K. Mohammed's exploration of the concept of martyrdom is an outstanding examination of the topic and stands out as one of the book's best essays. He gives a substantive, concise overview that perfectly frames the issue for both the novice and the specialist. It is unfortunately followed by Jonathan Ross' essay on Zentropism, a shining example of ivory-towered, impractical, navel-gazing. It undermines the book's credibility by its very presence.

Howard Clarke's essay on insider threats is one of the book's better offerings. His explanation of insider threats is a great start for any organization's strategic counter-intelligence plan. Keely M. Fahoum's treatment of Islamist thought and doctrine is a solid overview of the topic, while Dr. A. $\mathrm{K}$. Mohammed's discussion of suicide bombing is a trenchant piece of analysis and a useful reference point. Mohammed's ability to focus on his topic and bring to the fore what's important make his essays some of the book's best.

Dr. Monte R. Bullard's treatment of the battle of ideas examines Russian and Chinese thought. He discusses political warfare, the will of the people, asymmetric warfare, psychological operations, and cultural understanding as key elements that must be understood to effectively come to grips with homeland security issues. Next, David G. Popp's treatment of U.S./ European Union cooperation outlines the impact of cultural identity on Europe's Muslim populations. He does have a significant factual error. AlQaida did not commit the 1996 Khobar Towers attack. Iranian Hizbollah surrogates carried out the bombing. 
Dale L. June's essay on strategic security trends is a simultaneously rewarding and frustrating read. He masterfully weaves a wide array of classical and historical references into his tapestry, yet the stream-ofconsciousness jump from topic to topic leaves many substantive issues hanging unfinished. Many of the issues he mentions on the fly would be substantive topics well worth an essay or book to plumb the depth and breadth of their complexity. While his formidable intellect has certainly grappled with hard questions of where to go and how to get there, his solutions come across as facile-easy on paper, impractical to implement.

Keely M. Fahoum's treatment of Hamas and Hizbollah uses the political economy approach to examine them as viable political entities rather than terrorist groups. That is followed by Debra D. Burrington's impractical essay on "Diminution of the Citizen in the Age of Homeland Security." It is the worst type of sanctimonious, academic pap and undermines the overall credibility of the book. The Marxist undertones smack of leftover 1960 s twaddle with no practical value. Richard J. Niemann's examination of Chemical, Biological, Radiological, and Nuclear (CBRN) terrorism is also deeply flawed. There is no real analysis of the topic. He quotes multiple sources in a disjointed fashion and offers hypothetical "what if" scenarios.

Dale L. June's essay on apocalypse is a loosely organized, stream-ofconsciousness series of quotes and anecdotes touching on history, civics, psychology, literature, religion, sociology, and myriad other disciplines. Again, his biases rather than the topic itself take center stage. But Bart Bechtel's essay on community policing offers practical insights on how people at the grass-roots level can organize neighborhood watch efforts, and Wayne Taylor's essay on Human Intelligence (HUMINT) is a solid treatment of the topic, given the minimal space it occupies in the book.

Juan A. Bacigalupi's examination of terrorist threats in Latin America is, unfortunately, an inch deep and a mile wide. He obviously knows his topic, but a few paragraphs on each country are only enough to cover each of them at a superficial level. Next, Augusto D'Avila briefly discusses threat issues on the Mexican border emanating from drugs and cartels. Richard J. Niemann's treatment of chemical precursors in the construction of Improvised Explosive Devices (IED) outlines the increasing levels of sophistication in IED construction, as well as the danger to first responders.

Claudia M. Huiza's chapter on Panopti(con), like previous essays by Jonathan Ross and Debra D. Burrington, seriously lessens the book's credibility. But that is a conscious decision the editor made. Perhaps this 
Journal of Strategic Security

reviewer lacks the sophistication to truly understand the inclusion of these diamonds in the rough. Still, Dale L. June's final essay comes across more as a morning radio commentary.

Terrorism and Homeland Security is uneven from start to finish. Some essays are incredibly useful, and a few even border on brilliant. Unfortunately, many essays simply fill space. Despite its strengths, there are many other books on the topic that are much better for understanding the challenges faced by homeland security professionals. This book is best used selectively.

Mark J. Roberts, Homeland Security Subject Matter Expert 